\title{
Factors Influencing Succession Planning for Continuity of Family-owned Businesses in the Wa Municipality, Ghana
}

\author{
Rhoda Saan ${ }^{1, *}$, Francis Enu-Kwesi ${ }^{2}$, Remy Faadiwie Nyewie ${ }^{3}$ \\ ${ }^{1}$ Department of Building Technology and Estate Management, Wa Polytechnic, Ghana \\ ${ }^{2}$ Institute for Development Studies, University of Cape Coast, Ghana \\ ${ }^{3}$ West Gonja Hospital, Damongo, Ghana
}

Copyright $\bigcirc 2018$ by authors, all rights reserved. Authors agree that this article remains permanently open access under the terms of the Creative Commons Attribution License 4.0 International License

\begin{abstract}
The literature generally indicates that succession in family businesses takes the form of transfer from one generation to another, but succession planning appears to be left to chance by many firms. This neglect of succession planning and the emotions generated by the process make owners ill-prepared for succession. The objective of this study was to explore the factors that influence succession planning in family-owned businesses and their importance in ensuring the continuity and prosperity of businesses in the Wa Municipality, Ghana. A random sample of 205 out of 440 family businesses was systematically drawn, and an interview schedule was used to collect data which were analysed using descriptive and inferential statistics. The findings indicate that higher level of education of founders and communication of the succession decision, comprising the transfer date, and post-succession roles to all key stakeholders affect the succession process and the success of the transfer. When the founder's level of education is relatively high, there is the likelihood of succession planning in the business, but trust seems to be limited with respect to female owners. It is therefore recommended that family-owned businesses in the municipality should be encouraged by supervisory or oversight agencies like the registrar general or National Board for Small Scale Industries to improve their educational level, build trust, and set dates for transfer of responsibilities, specify post-succession roles of incumbents and communicate the succession decision to all key stakeholders in order to improve the succession process and ensure the continuity of the businesses.
\end{abstract}

Keywords Business, Continuity, Family-owned, Ghana, Planning, Succession

\section{Introduction}

Micro and small-scale rural and urban enterprises are major areas of importance to many policy makers in an attempt to accelerate the rate of growth in low income countries. These enterprises have been recognised as the engines through which the growth objectives of developing countries can be achieved. They are potential sources of employment and income in many developing countries. It is estimated that micro, small and medium enterprises (MSMEs), majority of which are family-owned businesses (FOBs), employ 22 percent of the adult population in developing countries [28]. Empirical studies show that MSMEs contribute to over $55 \%$ of GDP and over $65 \%$ of total employment in high-income countries. MSMEs and informal enterprises, account for over $60 \%$ of GDP and over $70 \%$ of total employment in low-income countries, while they contribute over $95 \%$ of total employment and about $70 \%$ of GDP in middle-income countries. In the European Union countries, for example, there are some 25 million small businesses, constituting $99 \%$ of all businesses; they employ almost 95 million people, providing $55 \%$ of total jobs in the private sector. Important contribution is also on exports and on productivity growth [54].

Small businesses create jobs, especially female employment, contribute to tax, export and import revenues, facilitate the distribution of goods, contribute to human resource development and are the cradle of innovations and entrepreneurship. Given their coverage, recommendation was made to government and policy makers to offer MSMEs financial and non-financial services to boost their growth and continuity. A report by the Families Business Review [26] reveals that less than one in three family businesses live into the second and about one in 10 make it to the third generation, with an average firm age of 24 years. Lam [42] cautioned on the dangerous and devastating effect of family business discontinuation which results in the loss of jobs, family assets and family relationships.

The European Commission estimates that there are 
around 1.5 million small businesses in Europe that have a high risk of failure as a result of succession problems [24]. A review of and tracking the failure rate of firms, shows that a high number of first generation firms and a large number of third generation firms file for bankruptcy. Harvie [36], in a review of MSMEs sector's contributions to the growth and development of East Asian economies, commends the sector's increasing importance to the region's recovery of sustained economic growth, employment, trade, investment, and the development of globally competitive economies. Beck, Demirguc-Kunt and Maksimovic [10] identified a positive relationship between the relative size of the MSMEs sector and economic growth. Indeed, it is discernible that a greater, more robust SME sector, could contribute revenue proportionate with their number, to national economies. It is in this context that many governments encourage investment in their economy by local and foreign entities. Despite the importance of succession to the continuity of family business, studies on succession and its impact on continuity of family business is in dearth.

Motwani and Schwarz [52] explain that succession is the explicit process by which a family business will be passed on to the family's next generation to manage and control. In their view, and as supported by Sharma, Chrisman, Pablo and Chua [64], succession planning is borne out of the family firm's intention to pursue succession for two reasons: activities related to succession planning are part of the succession process; and because succession planning increases the probability of a successful succession. What can be gleaned from the views of both authors is that succession is an event that confronts virtually all viable organisations. This notion had earlier been argued by Gephart [30] that succession is inevitable and, for this reason, it should be both anticipated and managed for the continuity of business organisations. What the argument connotes is that succession should be planned ahead to avoid the circumstance of a void, through death, dismissal, or internal relocation like transfer, promotion or demotion, in the management of family-owned businesses.

According to Rothwell [60], succession planning is a deliberate and systematic effort by an organisation to ensure leadership continuity in key positions, retain and develop intellectual and knowledge capital for the future, and encourage individual advancement. Similarly, Ip and Jacobs [38] explain that succession planning is a process which ensures the continued effective performance of an organisation by establishing a system to develop and replace key staff over time. In this context succession planning encompasses not only top management but also a number of other factors. It can cover issues such as the procedures necessary for a successful transfer, legal and financial considerations, psychological factors, leadership development, and exit strategies.

Wood [72] articulated that succession planning is a crucial factor for the continuity of businesses. This is emphasised in the accounting concept of going concern which stipulates that a business firm will continue to carry on its activities for an indefinite period of time. But for this to be a reality, businesses will have to pay more attention to succession planning. According to Meijaard, Mosselman, Frederiks and Brand [46], the significance of successful business transfer and the inherent pervasiveness of the business transfer challenge among small businesses was well documented. Succession is however, irrelevant just for the sake of it if the entity does not live to satisfy the expectations of stakeholders

The stakeholder theory [8], [21] explains that succession in a family business entails three components, comprising a leader who hands over the leadership role, a successor who takes over the role, and a mechanism by which the transition takes place. In this regard, Babicky [6] suggests the need for an agreement among family members to continue the business, while Handler [33] underscores the need for an acceptance among family members of their relative roles in the business. Like a well-run relay race, to be successful, the handing over of a company should be graceful, carefully strategised and well executed. A well-thought out succession plan is essential for the continuation of a business, regardless of its size and structure. The relay race theory gives an increased understanding to executive succession. Considering the analogy, the theory often uses the metaphor "passing the baton" in a $4 \times 100$ relay race [63]. This analogy emphasises the importance of exercising caution in order for successful passing of the baton, because dropping the baton leads to performance decrements or to complete performance failure and spells doom for the family and business stakeholders.

Researchers and consultants have long stressed the importance of succession planning in ensuring the continuity and prosperity of a business [70]. Some stated that dealing effectively with the issue of succession planning is the single most lasting gift that one generation can bestow upon the next [4]. Succession can represent a strategic opportunity for an organisation, particularly for those firms in growing and dynamic markets, not to mention rapidly growing firms whose managerial needs are changing [18]. The neglect of both the processual and the strategic aspects of succession are informed by intentions, attitudes and behaviour as the theory of planned behaviour suggests. This challenges the firm's future when delays assume a prolonged pattern to hand over or assume responsibility.

Scholars of family business argue that succession can lead to an important infusion of entrepreneurial energy based on the potential of new owners and managers to rejuvenate their firms [31], [53]. Scholars of entrepreneurship argue that the entrepreneurial process does not end with the creation of a new venture but that firm succession is a vital part of the entrepreneurship process [21]. Firm success can also be linked to successful 
succession management, which should elicit satisfaction with the succession process and ultimately lead to improved firm performance [33]. Thus, in a professionally managed firm with widely distributed ownership, financial performance may be the predominant goal, and success in management succession may be essentially a function of the firm's post-succession performance. Tagiuri and Davis [67] argue that with respect to family firms, however, maintaining good family relationships is also extremely important. At times, family members may give this goal a higher priority than profitability. It is in relation to the agency issues as postulated by agency theory that FOBs strive to retain the decision-making powers within the family.

The views expressed by the various authors above suggest that a conceptual argument can be made for an interactive relationship between these two dimensions of success in management succession. In essence, dissatisfaction with the succession process could cause interminable conflicts that make the succession ineffective. On the other hand, ineffective succession causes dissatisfaction with the succession process when the former situation dawns. In the opinion of Sharma, Chrisman, Pablo and Chua [63], satisfaction with the succession process is important because of its direct impact on the relationships among family members, and its impact on effectiveness.

Notwithstanding its importance, succession planning is a major problem within small, micro and medium enterprises. Garg and Weele [29], for instance, concluded that most of these entities are run by their founders or by a small management team and very few such operators have in place proper succession planning. They continued that the absence of proper succession planning can have the direct effect of causing the collapse of these businesses especially when key players leave the business upon retirement or in pursuit of other options. The exit or exodus of key stakeholders can make a business vulnerable and diminish its worth as investors will not invest in a business that is not sustainable. This can be particularly troublesome in countries, including Ghana where micro and small enterprises, mostly family-owned, dominate the economy.

According to Basu, Blavy and Yulek [10], Ghana's economy is largely characterised by micro and small scale enterprises (MSEs) who fulfil important roles through job creation, especially female employment, contribution to tax revenues, export and import revenues, facilitate the distribution of goods, contribute to human resource development and are the cradle of innovations and entrepreneurship [1]. Such characterizations apply to many businesses in the Wa Municipality of the Upper West Region which, like many micro and small enterprises, are family-owned. As such, they are susceptible to experiencing the challenges of succession that others face elsewhere, a challenge that has implications for business continuity, job creation for a large number of unemployed youth, tax contribution to the economy, and a source of living for families of owners in both short and long terms as suggested by Agyapong [1].

A report by Kuratko and Hodgetts [41] offered a general but limited idea about factors that affect family business. In general, the academic field of family business, especially as it pertains to succession planning has not received its deserved attention, given the enormous contributions that it makes to economies, and the dire consequences that failures of such businesses bring forth. In Spain, for instance, Bocatto, Gispert and Rialp [10] concluded that failure to provide succession was a primary cause for the demise of family-owned businesses. Prior to that, Ramona, Hoy, Poutziouris and Steier [58] emphasised that researches on family business are very slow or are being neglected by researchers in the field of entrepreneurship and business, and called for more studies to increase and advance understanding of family business.

The Ministry of Trade and Industry, in 1998, estimated that the Ghanaian private sector was dominated by MSMEs and consisted of approximately 80,000 registered limited companies and 220,000 registered partnerships [47]. According to Agyapong [1], data on micro, small and medium enterprises (MSMEs) in Ghana are not readily available. Nonetheless, what availed at the Registrar General indicated that 90 percent of firms registered were MSMEs and family owned, in the sense that the family has influence or control over both the ownership and management operations. Typically, with respect to many of these family owned micro and small enterprises, the owner's lifestyle was tied to the business and often times both the business and owner were inseparable. We therefore argue that the neglect of succession planning and the emotions generated by the process make owners ill-prepared for succession. Consequently, the challenge of succession planning by family-owned businesses in the Wa municipality, raises several issues and as a contribution, this paper sought to determine the factors that influence succession planning in family-owned businesses and their importance in ensuring the continuity and prosperity of businesses in the Wa Municipality. The rest of the paper discusses the theoretical and conceptual issues, followed by the methodology. The latter parts of the paper contain the results and discussion, conclusions and policy implications.

\section{Theoretical and Conceptual Discussions}

Succession planning is built on a number of theories in the literature. The theories discussed include agency cost, relay race, planned behaviour and stake holder, followed by concepts such as succession planning processes and succession issues in family-owned businesses. Agency cost theory encourages family-owned businesses' succession 
since it conveys the possibility that non-owner managers will not watch over the affairs of a firm as diligently as owners managing the firm themselves. In this respect, Fama and Jensen [25] argue in support of family ownership because it minimises agency problems, by allotting shares to agents whose special relations with other decision agents allow agency problems to be controlled without separation of the management and control decisions. An important consideration is that family members have many dimensions of exchange with one another with advantages in monitoring and disciplining related decision agents [25]. The relationships make it possible to transfer ownership from an incumbent to a successor without precluding the former from having anything to do with the firm.

Dyck, Mauws, Starke and Mischke [23] emphasised that the concept of succession could better be understood if the analogy of relay racing is considered, with attention on success factors such as sequence, timing, baton-passing technique and communication. In fostering successful succession planning, the four key factors in running a successful relay race, sequence, timing, baton-passing technique and communication [66] are examined to create a picturesque view and develop insights on how relay racing and succession relate. Absolute caution is the hallmark of successful baton-passing, otherwise the move can plunge the firm into reduced performance or complete failure [23]. The sequencing or ordering and timing are crucial in determining the success or otherwise of even the best team. Handler [34], [35], situating this in management paradigm, argues that it is discernible that the leadership baton is less likely to falter if the principals take the care and time needed to effect transfer, and communicate this to the stakeholders.

Communication is the lifeblood for information flow, understanding and cohesion in the family firm [7]. The foundation of the relay race demands team attributes of not only fast runners, but good communicators to ensure timely verbal prompting at the point of exchange. Davis and Tagiuri [20] and Morris, Williams, Allen and Avila [46] explain that the relevance of good communication between the incumbent and the successor in business is vital to eschew any syndrome of lack of trust, poor communication, conflict over strategy and process, or lack of a shared vision for the organisation, which could make succession problematic. All of these require conscious efforts by incumbents, successors and other stakeholders, as indicated by the tenets of the theory of planned behaviour.

Sharma, Chrisman and Chua [64] used the theory of planned behaviour to hypothesise the influence of the incumbent's desire to keep the business in the family, the family's commitment to the business, and the propensity of a trusted successor to take over on the extent to which family firms engage in succession planning activities. Other literature [2], [37] highlight the value of feasibility and self-efficacy in planned behaviour. Azjen [2] and Krueger and Carsrud [40] argued that for the sake of necessity, the components of succession planning should include selecting and training the successor, developing a post-succession business strategy, defining the post-succession role for the outgoing incumbent, and communicating the succession decision to key stakeholders.

Mahoney [45] broadly defines stakeholders as individuals and groups who contribute to the wealth-creating potential of the firm and are its potential beneficiaries and/or those who voluntarily or involuntarily become exposed to risk from the activities of a firm [57]. In this view, stakeholders embody shareholders, holders of options issued by the firm and debt holders as cited in OECD publications [55]. According to Morris, Rehbein, Hosseini and Armacost [50], and Blair [13], employees' local communities as well as the environment are all part of the stakeholders, including regulatory authorities, inter-organizational alliance partners, customers and suppliers [57].

However, Phillips [53] reported that it is inappropriate to interpret stakeholder theory as arguing for treating all stakeholders equally in disregard for differentials in contribution to the organisation. Similarly, Dentchev and Heene [22] argued that stakeholder management never implies that executives have to give equal attention to all stakeholder categories. In this case, attention and obligation can vary with each attribute operating on a continuum, or series of continua, unlike the case of a binary, "present" or "absent" term [56], [49]. Conversely, stakeholders, irrespective of their levels of contribution or stake in the firm, must be given attention but the succession route must be charted as policy or appropriateness dictates.

What can be inferred from the above postulations, and as argued by Motwani and Schwarz [52], is that succession planning is a pre-meditated process that spans a period of time and not an ad-hoc, one-time activity. When it is pre-planned and carefully implemented, taking into account, the dynamics of both family and business, there is the likelihood that the succession process will be successful and effective. According to Blotnick [14], the process of developing a post succession strategic plan for the company and defining the post-succession role of the departing incumbent should enhance communication within the family business. This will, in turn, play a great role in ensuring the success of succession [69], [71]. In essence, smooth and satisfactory succession is enhanced if the succession process seeks input from family stakeholders and develops a sense of ownership [37], [51].

Miller, Steier and Breton-Miller [48] argued that factors such as strategy, organisation, government and culture affect three major succession patterns, classified as conservative, wavering and rebellious successions. Lorna [43] also examined the implications for family-owned business successions and provided an integrative model of multiple stakeholder outcomes on succession. The framework indicated that the individual, organisation, 
family and environment are factors that affect succession process, because these form a system, where each factor affects and is affected by the others. Frishkoff [27] claimed that the choice of a successor may be influenced by the values of the family rather than the capabilities of the chosen successor. Frishkoff [27] continued that though family values cannot be downplayed, it is prudent to exercise pragmatism in the decisions on succession since such decisions impinge on the survival, growth and continuity of the firm, on which the family may depend largely for its livelihood.

According to Powell [57], successor selection is a rather difficult task because many firms become dependent on a dominant personality, founders detest relinquishing control, and some fear to have a diminished power when direct participation is allowed for others. Powell [57] stated that there is fear of losing control, losing their firms or of seeing them diminish or fail when someone else manages it, as well as the eruption of potential family quarrels that could damage the firm's existence when the founder retires or dies. A common deterrent factor found across theoretical and empirical studies suggests that these problems can be avoided and firm continuity assured through the preparation of an early succession plan [32].

According to Bird, Welsch, Astrachan and Pistrui [11], family business has been the strength and the power since the ancient economies. Aside their roles in the economic development of nations, they are effective engines of growth in terms of job creation and tax collections. Currently in Ghana, the private sector is seen as an engine of growth compared with the public sector as the latter is often accused of inefficiencies. It is therefore believed that a more robust private sector would complement government efforts and quicken national development efforts.

Small and medium-sized firms (SMEs), especially family businesses, have a great thrust on the world economy and are growing at a remarkable rate. According to Hamilton [32], many family businesses are micro enterprises ranging from micro firms run by the parents or "mom and pop" stores to firms as large as 500 employees and experienced tremendous growth to become with time, large corporations and mega firms. Hamilton argued that irrespective of their growth and success, family firms are exposed to numerous challenges peculiar to them, including selecting a successor, establishing criteria for succession, establishing the decision making process for family members' participation, delineating the firm's growth strategies and coordinating investment policies.

In succession discourse, continuity considerations are unavoidable if success is to be achieved in a business. Many business researchers, however, focus on succession and neglect its impact on business continuity. Succession is however, irrelevant just for the sake of it if the entity does not live to satisfy the expectations of stakeholders. According to Esuh et al. [24], business failures are a common feature amidst abundant studies on succession in family business. Esuh et al. [24] posited that the failures arose as the issue of succession and how it affects family business continuity was yet to be addressed. They proposed a conceptual framework on succession in relation to family business continuity, and concluded that the founder, successor and environment will jointly affect family business continuity and that true succession will mediate the relationship between founder, successor and environment on one hand and family business continuity on the other, as depicted by the model in Figure 1.

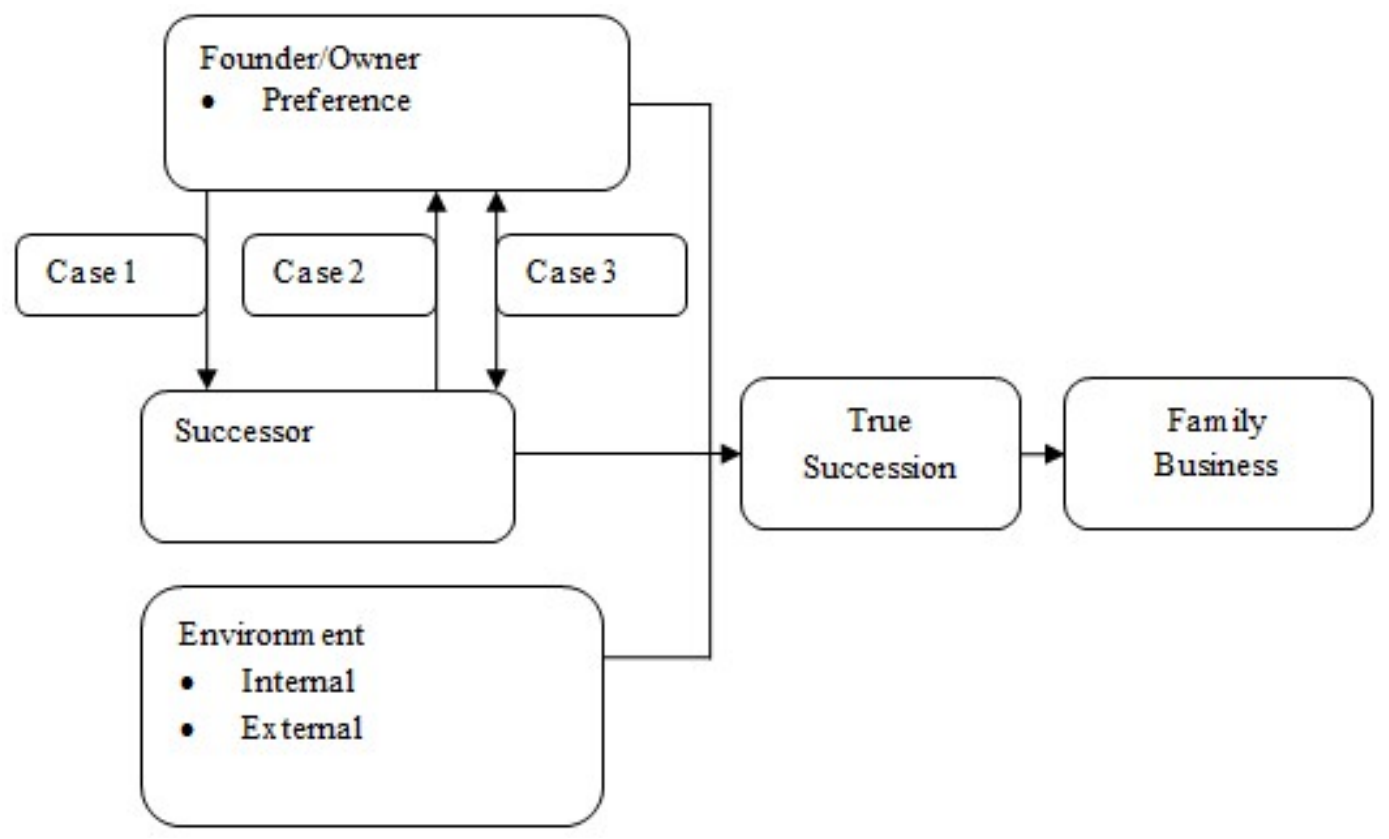

Source: Esuh et al., [24]

Figure 1. A conceptual model on succession 
The conceptual framework of our study is adapted from the conceptual model of Esuh et al. [24]. The model suggests that the founder, successor and environment will jointly affect family business continuity and that true succession will mediate the relationship between founder, successor and environment on one hand and family business continuity on the other. As much as our conceptual framework agrees with the model of Esuh et al. [24], we consider the effect of the succession process as equally paramount to succession and firm continuity as a key distinguishing feature. In the framework, we are also of the view that willingness of the founder to step aside, personal interest and competence/experience of the successor are inevitable considerations for a succession to be successful in a family business that purports to continue rather than liquidate.

In Figure 2, we present the adapted framework and how the various parts relate in order to achieve a successful succession that leads to continuity. The willingness of the founder or owner to step aside in preference for a successor either within or outside the family is an indication of the need for succession. The successor's personal interest and competence or experience facilitates his willingness to take over points to a possible succession. The environment, comprising both internal and external, together with the founder and the successor through the succession process will yield successful succession that leads to continuity.

Case 1 indicates the situation when the founder influences and initiates decisions on the succession process, using his coercive powers on the potential successor. Miller, Steier and Breton-Miller [43] posit that this constitutes conservatism in the approach as the founder's preference for a particular potential successor implies that the successor would follow the founder's method and approach in managing the family business. Such coercion is inappropriate and kills innovation and originality and may also trigger a family-wide unrest if there are a number of equally competent potential successors in the family.

Case 2 presents the scenario where the successor initiates the succession process with pressure on the founder to surrender power, authority, responsibility and control of the business to a new leadership. This potential successor could be branded as wavering or rebellious. However, in Case 3 both the founder and the successor have understanding on the need for the founder to step aside and for the successor to come on board and steer the affairs of the business. In conjunction with the right environment, the succession process will achieve a succession which is successful.

This mutuality of interest engenders agreement and discussion on how the founder relinquishes the leadership and management of the business to the successor. The succession process involves communication/consultation and training/mentorship and serves as the vehicle through which the founder, successor and environment will accomplish successful succession and lead to the family-owned business continuity. Stakeholder satisfaction with the succession process and choice of the successor is an indication of successful succession while the firm's growth measured by increase in size and the ability to develop and implement strategic plans depicts business continuity.

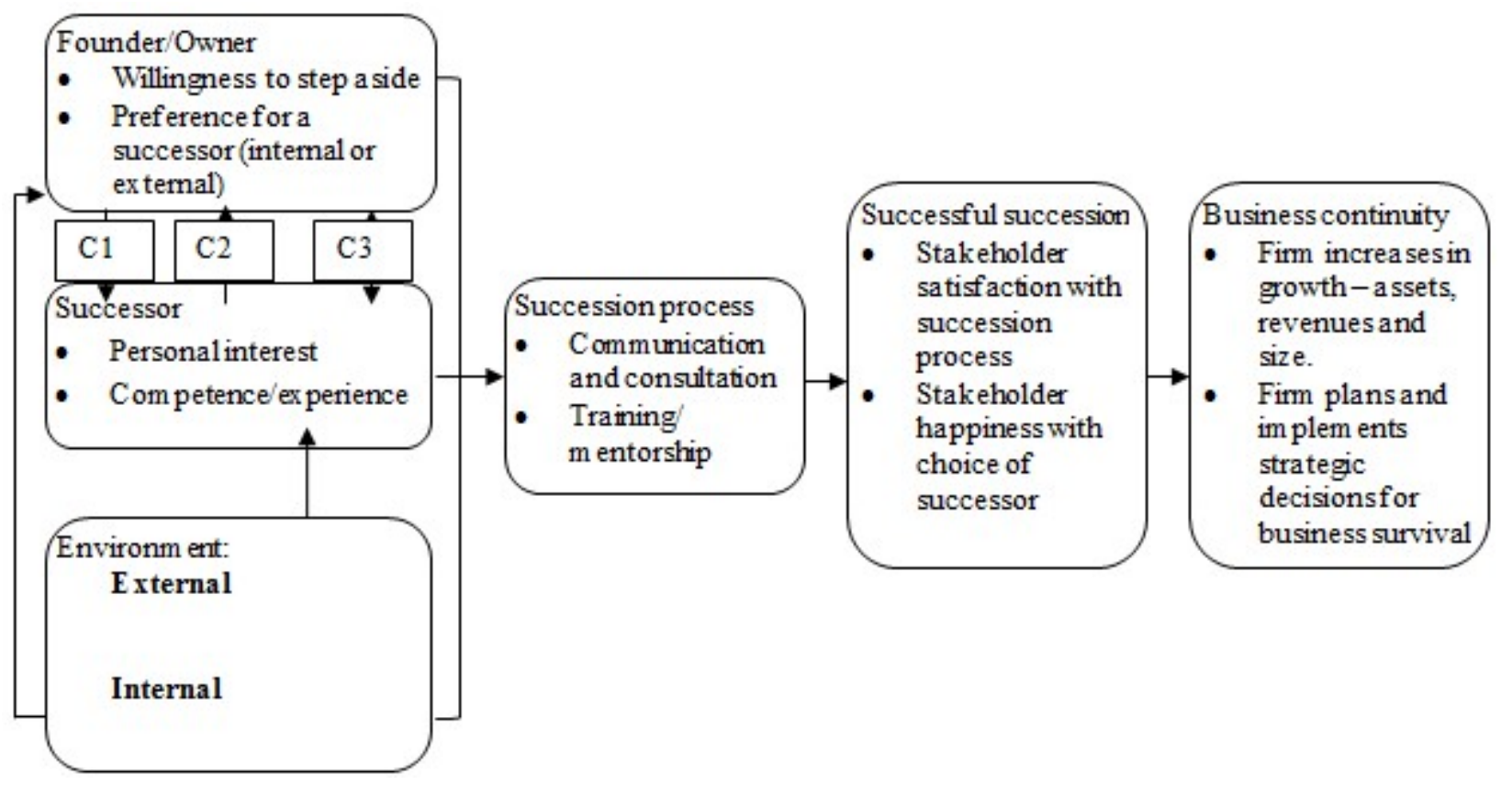

Source: Adapted from Esuh et al. (2011).

Figure 2. The model of succession and FOB business continuity 


\section{Methodology}

The Wa Municipality is predominantly populated by small and medium-sized enterprises, which are mostly owned and or managed by family members. Using an exploratory design, we set out to explore the factors that influence succession planning. Based on the conventional confidence level of 95 percent, with a margin of error of five percent [5], [69] and a targeted population of 440 $(\mathrm{N}=440)$ supplied by the National Board for Small Scale Industries, the sample size was computed as two hundred and five $(S=205)$. An exploratory study was chosen because there is no known study on the topic undertaken in the Municipality, thus presenting little information about the situation at hand and how similar issues were investigated in the past. In view of this phenomenon, extensive preliminary work was done to gain familiarity with the situation and to understand what is occurring before developing a model to set up a rigorous design for comprehensive investigation. The preliminary work revealed that family businesses in the municipality have significant family influence with fundamental interdependence of family, management, and ownership subsystems. These subsystems either work together in harmony for the growth of the business or in conflict with each other to destroy the business. Also, family firms in the study area are not homogeneous. They differ with respect to their inclination to pursue a business first or a family first philosophy. Thus, some FOBs place more value on family relationships while others place more value on profitability. They are owned and managed by the founding generations with succession not given sufficient attention.

The owner-managers or managers of these family-owned businesses were selected using the systematic random sampling technique based on a sampling fraction of 2.15 which was rounded up to 3 . The first sample unit was then randomly selected between 1 and 3 and from there, every $3^{\text {rd }}$ unit in the frame was selected to obtain the desired sample. Data were collected mainly from primary sources in quantitative forms. The primary data were gathered from respondents using an interview schedule. We considered the emotional and financial implications of the incumbent on the factors that influence succession planning by owners and therefore selected and analysed factors such as necessity for a date for transfer of responsibilities, the post-succession role of the departing incumbent, retirement sustenance package and communication of the succession decision to stake holders. The responses were captured on a 5 point scale with 1 showing weak agreement and 5 showing strong agreement. These were then analysed using descriptive statistics tools in SPSS. The collected data yielded a consistency co-efficient of 0.906 . The data were analysed using Spearman rank order bivariate correlation and cross tabulation (Chi square). The data were disaggregated into male only and female only respectively to further examine gender and succession options. Some of the items that were used to elicit responses were:

\begin{tabular}{|c|c|c|c|c|c|}
\hline Item & \multicolumn{5}{|c|}{ Rating } \\
\hline 1. A date for transfer of responsibility for day-to-day operations to successor is necessary in a succession plan. & 1 & 2 & 3 & 4 & 5 \\
\hline 2. Post-succession role of incumbent should include formal plan on roles and responsibilities. & 1 & 2 & 3 & 4 & 5 \\
\hline 3. Post-succession role of incumbent should include unwritten understanding of roles and responsibilities. & 1 & 2 & 3 & 4 & 5 \\
\hline 4. Post-succession role of incumbent should include a retirement sustenance package. & 1 & 2 & 3 & 4 & 5 \\
\hline 5. In the dissemination of succession decision, there should be communication to family members. & 1 & 2 & 3 & 4 & 5 \\
\hline 6. In the dissemination of succession decision, there should be communication to key employees. & 1 & 2 & 3 & 4 & 5 \\
\hline 7. In the dissemination of succession decision, there should be communication to other stakeholders. & 1 & 2 & 3 & 4 & 5 \\
\hline
\end{tabular}




\section{Results and Discussions}

The various background characteristics examined included gender, age, level of education, and number of employees. In all, there were 67.8 percent males and 32.2 percent females. Majority (99\%) of the current owners in the study area have had some level of formal education. About 28 percent of the total respondents have college education, 27.7 percent had Senior High School (SHS) or Technical school education while one percent had no formal education. Majority (74.6\%) of the enterprises in the municipality were established and managed by their current owners and therefore have not had any succession experience.

Table 1 shows the relationship that managers have with the business. About 76 percent of the respondents said that they were owners/founders of their businesses, while about six percent of the respondents were hired managers. Thus, majority of the businesses were owned and managed by the founders. This is consistent with the views of agency cost theorists [25] who encourage family successions and argue in support of family ownership in view of it being efficient to minimise agency problems.

Table 1. Relationship with the business

\begin{tabular}{ccc}
\hline Relationship & Frequency & Percent \\
\hline Owner or founder & 155 & 75.6 \\
Hired manager & 13 & 6.3 \\
Spouse of founder or owner & 13 & 6.3 \\
Son/Daughter of owner or founder & 11 & 5.5 \\
Other family relation & 13 & 6.3 \\
Total & 205 & 100.0 \\
\hline
\end{tabular}

Source: Field work (2012)

\section{Factors that Affect Succession Planning}

The responses to the founder, the successor, the succession process and the environment on the effectiveness of succession and firm continuity, necessity for a date for transfer of responsibilities, the post-succession role of the departing incumbent, retirement sustenance package and communication of succession decision to stake holders were captured on a 5-point scale with 1 showing weak agreement and 5 showing strong agreement.

The first item examined with regard to the components in a succession plan was the need for a date for the transfer of responsibility to be stated in the succession plan. The median response (5) indicated that the respondents strongly agreed that there was the need to always state a date for the founder to formally hand over responsibility for the day-to-day activity of the business to the successor (mean = 4.05 and skewness $=-1.211$ ). Secondly, with respect to the need for the founder to state a date for his or her planned retirement, the median response (5) is an indication that there was a strong agreement among the respondents that the planned retirement date should be stated in the succession plan $($ mean $=3.91$ and skewness $=-0.878)$. Similarly, there was strong agreement that a post-succession sustenance package should be outlined in the succession plan. The median response was five (mean $=$ 4.40 and skewness $=-1.84$ ), and this indicates that respondents agreed strongly with the need to have a post-retirement reliance sustenance package of the retiring CEO.

The results are consistent with the assertions of Dyck, Mauws, Starke, and Mischke [23] who use the relay race as an analogy for the succession process and describe the succession process as consisting of sequence, timing, technique, and communication. It also confirms the views of Dyck, Mauws, Starke and Mischke [23] that succession planning is a long-term process involving multiple activities and all activities should be examined independent of others. Sharma et al. [61] also added the need to define a role for the retiring CEO. The findings are thus consistent with the suggestion in the literature that the succession planning process consists of discrete components which include selecting and training a successor, developing a vision or strategic plan for the company after succession, defining the role of the departing incumbent, and communicating the decision to key stakeholders.

The relationship between education and succession planning was also explored. The results reveal that there is a significant relationship $\left(\chi^{2}=30.833\right.$, d.f. $=10$ and $\left.p=0.001\right)$ between the decision to plan for succession and the level of education of the owner/founder.

Owners or founders who have polytechnic or college and university education prefer written succession plans (Table 2). This implies that the higher the level of education one attains, the more likely one will have a better understanding of the importance of planning for the need to prepare for the transfer of their businesses as compared to those with lower levels of education. On the other hand, those with middle school or junior high school education are those who preferred unwritten succession plans, while those who had no succession plans generally had primary school and or senior high school education. This implies that the lower the level of education, the more likely it is that there will be no succession planning.

Table 2. Level of education and succession plans

\begin{tabular}{|c|c|c|c|c|c|}
\hline & & \multicolumn{3}{|c|}{ Which of these do you have? } & \multirow[b]{2}{*}{ Total } \\
\hline & & $\begin{array}{c}\text { Written } \\
\text { succession } \\
\text { plan }\end{array}$ & $\begin{array}{c}\text { Unwritten } \\
\text { succession } \\
\text { plan }\end{array}$ & None & \\
\hline \multirow{6}{*}{$\begin{array}{c}\text { Educational } \\
\text { background of } \\
\text { current } \\
\text { owner/manager }\end{array}$} & None & 0 & 1 & 1 & 2 \\
\hline & Primary & 0 & 3 & 6 & 9 \\
\hline & JHS & 8 & 18 & 10 & 36 \\
\hline & $\begin{array}{c}\text { SHS/Tech } \\
\text { Sch. }\end{array}$ & 23 & 16 & 18 & 57 \\
\hline & College/Poly & 34 & 18 & 6 & 58 \\
\hline & University & 23 & 11 & 9 & 43 \\
\hline \multicolumn{2}{|c|}{ Total } & 88 & 67 & 50 & 205 \\
\hline & College/Poly & 34 & 18 & 6 & 58 \\
\hline & University & 23 & 11 & 9 & \\
\hline & & 88 & 67 & & \\
\hline
\end{tabular}

$\chi^{2}=30.833, \mathrm{df}=10$ and $\mathrm{p}=0.001$ Source:

Field work (2012) 
Another factor that affects the succession planning process and successful transfer in business is communication. Just like every decision making process, communication to all stakeholders is very necessary for the success of the succession decision as depicted in the conceptual framework (Figure 2). The analysis for this variable was in respect of the various stakeholders within the family business for all 205 respondents. It was observed that 73.7 percent of owners or founders strongly agreed that there should be communication of the succession decision to family members. Also, 71.2 percent strongly agreed that there should be communication with key employees, while 56.1 percent indicated very strong agreement that there should be communication of the succession decision to other stakeholders. This finding is consistent with that of Barnes and Hershon [7], Davis and Tagiuri [20] and Morris et al. [51] that communication is the lifeblood for information flow, understanding and cohesion in the family firm. The relevance of good communication between the incumbent and the successor in business is vital to avoid mistrust, insufficient communication, conflict over strategy and process, and for sharing a vision for the organisation, in order to make succession successful.

The relationship between the desire of the founder for succession and communication was explored using Spearman rank order bivariate correlation. The results show that there were significant relationships among all the variables (Table 3). With regard to the desirability of founders for succession and communication of the succession decision to family members, there was a significant positive relationship $(\mathrm{r}=0.240, \mathrm{p}=0.001, \mathrm{~N}=$ 205 ) at 0.01 alpha level (2-tailed). Correlations between the other variables were also significant (Table 3 ). The results are in conformity with the conclusion of Sharma et al. [63], that the succession decision should be communicated to key stakeholders. It also reflects the conceptual framework of the study adapted from the model of Esuh et al. [24] that through communication and consultation in the succession planning process, stakeholder satisfaction with the process will lead to successful succession and business continuity.

The need for communication of the succession decision to family members, key employees and other stakeholders were further explored in relation to gender. The results show that there is no significant relationship $\left(\chi^{2}=5.753\right.$, d.f. $=4, p=0.218)$. Thus, both males and female respondents are of the view that the succession decision should be communicated to family members. The results for communication to key employees also showed no significant difference with respect to sex of the respondents $\left(\chi^{2}=37.161\right.$, d.f. $=4$ and $\left.p=0.128\right)$.

On the other hand, communication of the decision to other stakeholders revealed a significant relationship with gender, $\left(\chi^{2}=18.321\right.$, d.f. $=4$ and $\left.p=0.001\right)$. It was observed that 66.1 percent of male respondents agreed strongly that the succession decision should be communicated to other stakeholders, while 33.9 percent of female respondents shared this view. It means that for communication of the succession decision to other stakeholders, there were differences in opinion between males and females. This finding is consistent with the views of Branco and Rodrigues [15], that, the impacts of the various stakeholders are not equal as they do not carry the same weight and stakes, and risks may vary in significant proportions. Therefore, on succession matters in family firms, the various stakeholders might exert thrust in the decision process according to their relative interest, stake and contribution to the firm.

To further examine the factors that influence succession planning and business continuity, a cross tabulation was carried out to examine the relationship between the sex of respondents and the succession options opened to founders or owners of family businesses. The results showed a significant relationship between gender and succession options (Table 4). It was observed that more males $(70.5 \%)$ than females $(29.5 \%)$ indicated that they prefer the appointment of a family member. Secondly, 68.8 percent of the male respondents indicated that they prefer the appointment of a caretaker manager whereas only 30.2 percent of female respondents preferred the appointment of a care taker manager. On the other hand, 88.3 percent of females were in favour of the appointment of a professional manager. From the foregoing, it is evident that in terms of succession options, there were significant differences between males and females.

Table 3. Correlation coefficients of explanatory variables

\begin{tabular}{|c|c|c|c|c|c|}
\hline Variables & Spearman & $\begin{array}{l}\text { Desire for } \\
\text { succession }\end{array}$ & $\begin{array}{l}\text { Comm. to } \\
\text { fam. } \\
\text { mem. }\end{array}$ & $\begin{array}{l}\text { Comm. to key } \\
\text { empls }\end{array}$ & $\begin{array}{l}\text { Comm. to other } \\
\text { stakehs }\end{array}$ \\
\hline Desire for succession & Coeff. Sig. & 1.00 & $\begin{array}{c}0.240^{* *} \\
0.001\end{array}$ & $\begin{array}{c}0.328^{*} \\
0.000\end{array}$ & $\begin{array}{c}0.472 * * \\
0.000\end{array}$ \\
\hline $\begin{array}{l}\text { Communication to family } \\
\text { members }\end{array}$ & $\begin{array}{l}\text { Coeff. } \\
\text { Sig. }\end{array}$ & $\begin{array}{c}0.240 * * \\
0.001\end{array}$ & 1.00 & $\begin{array}{c}0.512 * * \\
0.000\end{array}$ & $\begin{array}{c}0.475 * * * \\
0.000\end{array}$ \\
\hline Communication to key employees & $\begin{array}{l}\text { Coeff. } \\
\text { Sig. }\end{array}$ & $\begin{array}{c}0.328 * * \\
0.000\end{array}$ & $\begin{array}{l}0.512 * * \\
0.000\end{array}$ & 1.00 & $\begin{array}{c}0.686^{* *} \\
0.000\end{array}$ \\
\hline $\begin{array}{c}\text { Communication to other } \\
\text { stakeholders }\end{array}$ & $\begin{array}{l}\text { Coeff. } \\
\text { Sig. }\end{array}$ & $\begin{array}{c}0.472 * * \\
0.000\end{array}$ & $\begin{array}{c}0.475^{* *} \\
0.000\end{array}$ & $\begin{array}{c}0.686^{* *} \\
0.000\end{array}$ & 1.00 \\
\hline
\end{tabular}

**- Correlation is significant at 0.01 level.

Source: Fieldwork (2012) 
Table 4. Gender and succession options

\begin{tabular}{|c|c|c|c|c|c|c|c|}
\hline & \multicolumn{4}{|c|}{ Succession options-appoint } & \multirow{2}{*}{ Total } \\
\hline & & & Family member & Caretaker manager & professional manager & Liquidate & \\
\hline \multirow{8}{*}{ Gender } & \multirow{4}{*}{ Male } & Count & 93 & 44 & 1 & 1 & 139 \\
\hline & & $\%$ within Gender & $66.9 \%$ & $31.7 \%$ & $0.7 \%$ & $0.7 \%$ & $100.0 \%$ \\
\hline & & $\%$ within succession options & $70.5 \%$ & $68.8 \%$ & $16.7 \%$ & $33.3 \%$ & $67.8 \%$ \\
\hline & & $\%$ of Total & $45.4 \%$ & $21.5 \%$ & $0.5 \%$ & $0.5 \%$ & $67.8 \%$ \\
\hline & \multirow{4}{*}{ Female } & Count & 39 & 20 & 5 & 2 & 66 \\
\hline & & $\%$ within Gender & $59.1 \%$ & $30.3 \%$ & $7.6 \%$ & $3.0 \%$ & $100.0 \%$ \\
\hline & & $\%$ within succession options & $29.5 \%$ & $31.3 \%$ & $83.3 \%$ & $66.7 \%$ & $32.2 \%$ \\
\hline & & $\%$ of Total & $19.0 \%$ & $9.8 \%$ & $2.4 \%$ & $1.0 \%$ & $32.2 \%$ \\
\hline \multirow{4}{*}{\multicolumn{2}{|c|}{ Total }} & Count & 132 & 64 & 6 & 3 & 205 \\
\hline & & $\%$ within Gender & $64.4 \%$ & $31.2 \%$ & $2.9 \%$ & $1.5 \%$ & $100.0 \%$ \\
\hline & & $\%$ within succession options & $100.0 \%$ & $100.0 \%$ & $100.0 \%$ & $100.0 \%$ & $100.0 \%$ \\
\hline & & $\%$ of Total & $64.4 \%$ & $31.2 \%$ & $2.9 \%$ & $1.5 \%$ & $100.0 \%$ \\
\hline
\end{tabular}

$\chi^{2}=9.271$, d.f. $=3$ and $p=0.026$ Source: Field work (2012)

Table 5. Gender (female only) and succession options

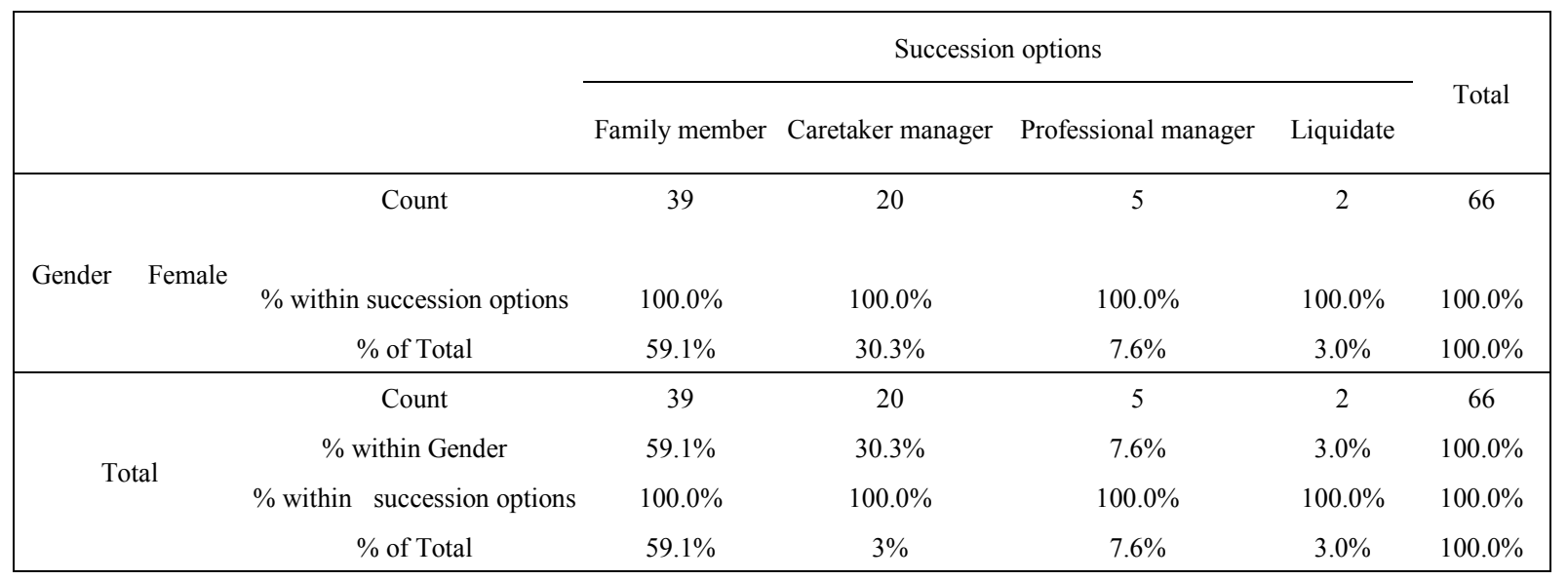

$\chi^{2}=9.271, \mathrm{df}=3$ and $\mathrm{p}$-value $\left.=0.026\right)$ Source: Field work (2012)

But when the data were disaggregated and only the female respondents were selected. Their responses were cross tabulated with the types of succession options they preferred. The result shows that when only the female category was considered, the option most preferred (59.1\%) was the appointment of a family member and the least preferred $(3.0 \%)$ option was liquidation of the business (Table 5).

Similarly, when the data were disaggregated and only the male respondents were selected and cross tabulated with the types of succession options they preferred, the result showed that 66.9 percent preferred the appointment of a family member while 0.7 percent would either appoint a professional manager or liquidate the business. It was observed that the preference of male and female did not differ when the data were disaggregated. This finding is consistent with agency cost theory which encourages family successions since it gives the idea that non-owner managers will not watch over the affairs of a firm as diligently as owners managing the firm themselves. Fama and Jensen [25] argue in support of family ownership in view of it being efficient to minimise agency problems because shares are in the hands of agents whose special relations with other decision agents allow agency problems to be controlled without separation of the management and control decisions.

\section{Conclusion and Policy Implications}

It can be concluded that highly educated business owners are likely to write down their succession plans as compared to their lowly educated counterparts. The business owners also recognize the need for a date for the transfer of responsibility to be set and communicated to family members. However, male owners were more inclined to communicate such decisions to other key stakeholders, while the female owners were less inclined to do so. Additionally, while female owners preferred the appointment of professional managers, the male owners would rather appoint family members as care taker managers.

The conclusions show that educations is important for succession planning and continuity of family owned businesses, and it is therefore incumbent upon the training and support agencies within the municipality to encourage business owners to further their education. The fact that female owners would not want to communicate the succession decision to other stakeholders, but prefer professional managers to family members while the male 
owners would communicate the decision to other stakeholders but appoint family members as care takers shows that there are different levels of trust. It appears that the females have limited trust in family members as care takers and limited trust in other stakeholders. These limitations pose threats to the business continuity of female-owned enterprises and therefore require urgent attention by the support and other agencies. There is a need for them to inculcate trust building as part of their training and support systems in order to improve survivability of female-owned enterprises because it has implications for reducing poverty levels.

\section{Acknowledgements}

I am greatly indebted to the owners and managers of the family owned businesses in $\mathrm{Wa}$, for their valuable time and tremendous contributions toward the completion of my thesis. I am also indebted to Prof. Godwin Kwaku Senanu Aflakpui for his meticulous editing and inputs for this paper, and to all friends and family members for diverse contributions, especially, Ms Rose Saan and Dr. Yao Martin Donani.

\section{REFERENCES}

[1] Agyapong, D. (2010). Micro, small and medium enterprises' activities: Income level and poverty reduction in Ghana: A synthesis of related literature. International Journal of Business and Management, 5 (12), 196-205.

[2] Ajzen, I. (1987). Attitudes, traits and actions: Dispositional prediction of behaviour in social psychology. Advances in Experimental Psychology, 20, 1-63.

[3] Ajzen, I. (1991). The theory of planned behaviour. Organisational Behaviour and Human Decision Processes, 50, 179-211.

[4] Ayres, G. (1998). Rough corporate justice. Family Business Review. 11(2), 91-106.

[5] Babbie, E. (2007). The practice of social research (11 ${ }^{\text {th }}$ ed.). Belmont, CA: Wadsworth Cengage Learning.

[6] Babicky, J. (1987). Consulting to the family business. Journal of Management Consulting, 3 (4), 25-32.

[7] Barnes, L. B. \& Hershon, S. A. (1976). Transferring power in the family business. Harvard Business Review, 54, 105114.

[8] Barry, B. (1975). The development of organization structure in the family firm. Journal of General Management, Autumn, 42-60.

[9] Basu, A., Blavy, R. \& Yulek, M (2004) Microfinance in Africa: Experience and Lessons from IMF. Washington DC: International Monetary Fund.

[10] Beck, T., Demirguc-Kunt A. \& Maksimovic, V. (2004).
[11] SMEs, Growth, and poverty - Do pro-SME policies work? World Bank Policy Research Working Paper No. 268.

[12] Bird, B., Welsch, H., Astrachan, J.H. \& Pistrui, D. (2002). Family Business Research: The evolution of an academic field. Family Business Review. 15 (4), 337-350.

[13] Bocatto, E., Gispert, C., \& Rialp, J. (2010). Family-Owned Business Succession: The Influence of Pre-performance in the Nomination of Family and Nonfamily Members: Evidence from Spanish Firms. Journal of Small Business Management, 48, 497-523.

[14] Blair, M. (1996). Wealth Creation and Wealth Sharing. Washington, D.C.: Brookings.

[15] Blotnick, S. (1984). The case of the reluctant heirs. Forbes, (July 16), 134, 180.

[16] Branco, M.C. \& Rodrigues, L.L. (2007). Positioning stakeholder theory within the debate on corporate social responsibility. Electronic, Journal of Business Ethics and Organisation Studies, 12, (1), 5-15. Retrieved from http://ejbo.jyu.fi/pdf/ejbo_vol12_no1.

[17] Churchill, N. C. \& Lewis, V. L., (1983). The five stages of small business growth. Harvard Business Review, 61 (3), $30-50$.

[18] Chrisman, J. J. (1999). The influence of outsider generated knowledge resources on venture creation. Journal of Small Business Management, 37 (4), 42-58.

[19] Daily, C. M. \& Dollinger, M. J. (1992). An empirical examination of ownership structure in family and professionally managed firms. Family Business Review, 7 (3), 237-250.

[20] Davis, J. A. (1982). The influence of life-stage on father-son work relationships in family companies. Doctoral dissertation. Harvard Business School.

[21] Davis, J. A. \& Tagiuri, R. (1989). The influence of life-stage on incumbent -son work relationships in family companies. Family Business Review, 2 (1), 47-74.

[22] Detienne, D. (2010). Entrepreneurial exit as a critical component of the entrepreneurial process: Theoretical development. Journal of Business Venturing, 25(2), 203-215.

[23] Dentchev, N. \& Heene, A. (2003). Toward stakeholder responsibility and stakeholder motivation: Systemic and holistic perspectives on corporate responsibility.

[24] Dyck, B., Mauws, M., Starke, F. A. \& Mischke, G. A. (2002). Passing the baton: The importance of sequence, timing, technique and communication in executive succession. Journal of Business Venturing, 17, 143-162.

[25] Esuh, O. L., Mohd, S. M. \& Adebayo, O. I. (2011). A conceptual framework of family business succession: Bane of family business continuity. International Journal of Business and Social Science, 2, 18.

[26] Fama, E. \& Jensen, M. (1983). Separation of ownership and control. Journal of Law and Economics, 26, 301-325.

[27] Family Business Magazine (2002). The world's largest family companies. Retrieved from www/familybusiness magazine.com/topglobal.html. 
[28] Frishkoff, P. A. (1994). Succession need not tear a family apart. Best's Review, 95(8), 70-73.

[29] Gallagher, C., \& G. Robson (1995). Small business and job creation: An evenfurther dissection of the Davis, Haltiwanger and Schuh Working Paper. International Small Business Journal, 13, 64-67.

[30] Garg, A. K., \& Weele, E. V. (2012). Succession planning and its impact on the performance of small micro and medium enterprises within the manufacturing sector in Johannesburg. International Journal of Business and Management, 7(9), 96-107.

[31] Gephart, R. P. (1978). Status degradation and organizational succession: An ethno-methodological approach. Administrative Science Quarterly, 23, 553-581.

[32] Habbershon, T. G. \& Pistrui, J. (2002). Enterprising families domain: Family-influenced ownership groups in pursuit of trans-generational wealth. Family Business Review, 15, 223-237.

[33] Hamilton, L. (2003). SMES succession planning: Its pros and cons, a survival process. In International Council for Small Business, 48th World Conference, Belfast, UK.

[34] Handler, W. C. (1989). Managing the family firm succession process: The next generation family member's experience. Doctoral dissertation. School of Management: Boston University.

[35] Handler, W. C. (1990). Succession in family firms: a mutual role adjustment between entrepreneur and next-generation family members. Entrepreneurship Theory Practice, 15, 3751.

[36] Handler, W. C. (1992). The succession experience of the next generation. Family Business Review, 5 (3), 283-307.

[37] Harvie, C. (2004). East Asian SME capacity building, competitiveness and market opportunities in a global economy. Retrieved from

http://www.uow.edu.au/commerce/econ/wpapers.html.

[38] Hayes, J. T. \& Adams, R. M. (1990). Taxation and statutory considerations in the formation of family foundations. Family Business Review, 3 (4), 383-394.

[39] Ip, B., \& Jacobs, G. (2006). Business succession planning: a review of the evidence. Journal of Small Business and Enterprise Development, 13, 236-350.

[40] Krueger, N. F. Jr. (1993). The impact of prior entrepreneurial exposure on perceptions of new venture feasibility and desirability. Entrepreneurship Theory and Practice, 18 (1), 5-21.

[41] Krueger, N. F. Jr., \& Carsrud, A. L. (1993). Entrepreneurial intentions: Applying the theory of planned behaviour. Entrepreneurship and Regional Development, 5, 315-330.

[42] Kuratko, D. K. \& Hodgetts, R. M. (2004). Entrepreneurship: Theory, process and practice $\left(6^{\text {th }}\right.$ ed). United. States of American: Thomson South-Western.

[43] Lam, J. (2009). Succession process in a large Canadian family business: A longitudinal case study of the Molson Family Business: 1786-2007. Family Business Review, 1 (2), 119-143.
[44] Lorna, C. (2011). Implications for family-owned business successions: A multiple perspectives review and suggestions for further research.

[45] Meijaard, J., L. Uhlaner, R. Flören, B. Diephuis \& B. Sanders (2005). The relationship between successor and planning characteristics and the success of business transfer in Dutch SMEs, EIM, Zoetermeer

[46] Mahoney, J.T. (2005). Economic foundations of strategy. Thousand Oaks, CA: Sage Publications.

[47] Meijaard, J., M. Mosselman, K.F. Frederiks and M.J. Brand (2002), Organisatietypen in het $M K B$, eenverkennend onderzoeknaar de organisatiestructuren van het midden- en kleinbedrijf [Organizationalstructures in SMEs: an exploration], EIM, Zoetermeer.

[48] Mensah, S. (2004). A review of SME financing schemes in Ghana. UNIDO Regional Workshop of Financing SMEs, 15-16 March, Accra.

[49] Miller, D., Steier, L., \& Breton-Miller, I. L. (2003). Lost in time: Intergenerational succession, change, and failure in family business. Journal of Business Venturing, 18 (4), 513-531.

[50] Mitchel, R. K., Wood, J. D., \& Agle, B. R. (1997). Towards a theory of stakeholders' identification and salience: Defining the principle of who and what really counts. Academy of Management Review, 22 (4), 853-887.

[51] Morris, S. A., Rehbein, A. K., Hosseini, C. J., \& Armacost,

[52] A. R. (1990). Building a current profile of socially responsive firms. IAB Proceedings, 297-303.

[53] Morris, M. H., Williams, R. O., Allen, J. A. \& Avila, R., A. (1997). Correlates of success in family business transitions. Journal of Business Venturing, 12 (5), 385-401.

[54] Motwani, J. \& Schwarz, T. V. (2002). Succession planning practices of West Michigan family-owned businesses: An empirical analysis. Retrieved from www.sbaer.uca.edu/research/sbida/2002/Papers/24.pdf

[55] Nordqvist, M. \& Melin, L. (2009). Entrepreneurial families and family firms. Entrepreneurship and Regional Development (accepted and forthcoming).

[56] OECD [Organisation for Economic Co-operation and Development ] (2009), The Impact of the Global Crisis on SME and Entrepreneurship Financing and Policy

[57] Responses, OECD Publications, [available at http://www.oecd.org/dataoecd/40/34/43183090.pdf].

[58] Phillips, R. (2003) Stakeholder theory and organisational ethics. San Francisco, CA: Berrett-Koehler.

[59] Post, J. E., Preston E. L. \& Sachs, S. (2002). Redefining the corporation: Stakeholder management and organizational wealth. Stanford, CA: Stanford University Press.

[60] Powell, D. (2003). Business strategies: Family businesses succession. Part of a counseling series on Family Businesses, Legal Center, US Small Business Administration.

[61] Ramona, K. Z., Hoy, F., Poutziouris, P. Z. \& Steier, L. P. (2008). Emerging paths of family entrepreneurship research. Journal of Small business Management, 46 (3), 317-330 
[62] Rothwell, W. (2001). Effective succession planning: Ensure leadership continuity and building talent from within (2nd ed.). AMACOM, New York. NY.

[63] Saunders, M., Lewis, P., \& Thornhill, A. (2009). Research methods for business students ( $5^{\text {th }}$ ed.). Edinburgh Gate, Harlow: Pearson Education.

[64] Sharma, P., Chua, J. H. \& Chrisman, J. J. (2000). Perceptions about the extent of succession planning in Canadian family firms. Canadian Journal of Administrative Sciences, 17, 233-244.

[65] Sharma, S., \& Starik, M. (2003). 117-139. Stakeholders, the environment and society: New perspectives in research on corporate responsibility (pp117-19). Northampton: Edward Elgar Publications.

[66] Sharma, P., Chrisman, J. J., Pablo, A. L., \& Chua, J. H. (2001). Determinants of initial satisfaction with the succession process in family firms: A conceptual model. Entrepreneurship Theory and Practice, 25 (3), 17-35.

[67] Sharma, P., Chrisman, J. J. \& Chua, J. H. (2003). Succession planning as planned behavior: Some empirical results. Family Business Review, 16 (1), 1-15.
[68] Sheppard, B., Hartwick, J., \& Warshaw, P. (1988). The theory of reasoned action: A meta-analysis of past research with recommendations and future research. Journal of Consumer Research, 15, 325-344.

[69] Steben, R. E. \& Bell, S. (1978). Track and field: An administrative approach to the science of coaching. New York: Wiley.

[70] Tagiuri, R., \& Davis, J. A. (1992). On the goals of successful family companies. Family Business Review, 5, 43-62.

[71] Trow, D. B. (1961). Executive succession in small companies. Administrative Science Quarterly, 6, 228-239.

[72] Vancil, R. F. (1987). Passing the baton: Managing the process of CEO succession. Boston, MA: Harvard Business School Press.

[73] Ward, J. L. (1987). Keeping the family business healthy: How to plan for continuing growth, profitability, and family leadership. San Francisco: Jossey-Bass.

[74] Wood, S. (1999). A Family-friendly management: Testing the various perspectives? National Institute Economic Review, 168, 99-116. 